\title{
DIE ROL VAN DIE ETIEK IN DIE PREDIKING: NUWE NAVORSING IN NuWE TESTAMENTIESE ETIEK EN DIE IMPLIKASIE DAARVAN VIR DIE PREDIKING
}

Author:

Kobus Kok ${ }^{1}$

\section{Affiliation:}

${ }^{1}$ Departement Nuwe

Testament Studies,

Universiteit van Pretoria,

Suid-Afrika

Correspondence to:

Kobus Kok

email:

kobus.kok@up.ac.za

Postal address:

Departement Nuwe

Testament Studies, Fakulteit

Teologie, Universiteit van

Pretoria, Lynnwoodstraat,

Hatfield 0083, Pretoria,

Suid-Afrika

Keywords:

etiek; hermeneutiese; wettiesheid; moraliteit; prediking; hervormde

Dates:

Received: 09 Feb. 2010

Accepted: 17 Aug. 2010

Published: 08 Nov. 2010

How to cite this article: Kok, J., 2010, ‘Die rol van die etiek in die prediking: Nuwe navorsing in Nuwe Testamentiese etiek en die implikasie daarvan vir die prediking, Verbum et Ecclesia 31(1), Art. \#375, 10 pages. DOI: $10.4102 /$ ve.v31i1.375

\section{This article is available} at: http://www.ve.org.za
C 2010 . The Authors. Licensee: OpenJournals Publishing. This work is licensed under the Creative Commons Attribution License.

\begin{abstract}
The role of ethics in preaching: New research in New Testament ethics and the implication for preaching

To the Reformers, legalism was one of the greatest dangers that threatened the heart of preaching and Christian life in general. Luther argued that where preaching solidifies and degenerates into legalism, the essence of the gospel of grace is lost. Therefore, the dynamic relationship between identity, ethics and ethos in the New Testament has to be rediscovered. It is argued that the classical Bultmanian distinction between indicative and imperative does not do justice to the implicit ethical dimension of Biblical texts. New research into ethics, represented by Zimmermann's heuristic categories, may help us in rediscovering the implicit ethical dimensions in the New Testament. Those who want to speak of the theology of ethical preaching should also take the new research in New Testament ethics into consideration.
\end{abstract}

\section{INLEIDING}

Wettisisme was vir die Reformatore die grootste gevaar wat die prediking bedreig het. Luther het gesê dat waar die prediking wetties raak, daar niks meer van die genade van die evangelie oorbly nie. Vir Luther was die korrekte verstaan van die verhouding tussen wet en evangelie van kardinale belang. Wettiese prediking word gekenmerk deur min indikatiewe en baie imperatiewe. Dit is prediking waar die vermoë van die gebroke mens in sy of haar vervallenheid oorskat word en die verlossingsdaad van Christus en die genade van God in die evangelie onderskat word. Kortweg, dit fokus dermate op die mens en die wette en reëls wat hy of sy moet nakom, dat God uit die oog verloor word:

Wettiese preke is prinsipieel oneskatolgies. Hoop as in uitsig op die beloftes van God word vervang deur die verbete vroomheid van die godsdienstige mens. In die plek van die belofte van God (promissio Dei) kom die potensiaal van mense (potentia populi). In' $n$ sin word die sirkel hier voltooi: nie alleen val 'n gesonde ktisiologie (skeppingsleer ...), uit wettiese preke weg nie, maar ook die eskatologie.

(Cilliers 2004:84)

Saam met Johan Cilliers $(1996,2000)$ kan ons sê dat hierdie tipe prediking hom by wyse van spreke besig hou met die annihilatio Dei of 'uitwissing van God op die kansel' (kyk ook Cilliers 2004:83). Hierteenoor staan die 'hermeneutiese model vir evangelieprediking' wat poog om hierdie dergelike probleem te oorkom. Laasgenoemde lei in die eerste instansie tot die hernude 'uitwysing van God op die kansel'. Hier staan God en sy handelinge, en nie die mens nie, in die sentrum. Die prediker kommunikeer dan meer oor wat God doen en minder oor wat die gevalle mens kan doen (Cilliers 2004:38). So leef ons as Bybelse pelgrims 'agteruit vorentoe' (Joubert 2010:38) met nuwe hoop (Long 2009:64) wat gewortel is in die groot verlossingsdade van God in die ryke verlede - en doen ons dit saam as geloofsgemeenskap wat mekaar help vorm in lyn met die (herontdekte) begrondingsnarratief van ons geloof (Van der Watt 2005:247-259).

In hierdie artikel word daar besin oor die rol wat die etiek in die prediking kan speel. Daar sal ook besin word oor ' $n$ teologies verantwoorde manier om morele kwessies in die prediking aan die orde te stel en hoe om wettiese moralisme te vermy.

\section{DIE SKETSING VAN DIE DEKOR}

\section{Die ganse wêreld in transito}

Elke tydperk in die geskiedenis kan waarskynlik daarop aanspraak maak dat dit'n tyd van verandering of transformasie was, maar sommiges meen dat die wêreld (en die kerk in die wêreld) tans 'n radikale oorgang en gevolglike verandering (Joubert 2010:37; Miller 2004; Niemandt 2007:9; Peeters 2003:27) beleef wat wesenlike implikasies inhou vir hoe ons oor onsself, ons wêreld, die kerk (Miller 2004:xi) en God dink (Smit 1995:9; Spangenberg 2003:147-160, 2004:274-293). Hierdie oorgang hou nie net verband met die ingrypende veranderings wat die demokratiseringsproses in die Suid-Afrikaanse samelewing teweeg gebring het nie (Joubert 2008:1-2); breër globale prosesse speel ook 'n rol (Miller 2004:ix). Sommige geleerdes meen dat ons nou 'n soortgelyke oorgang beleef as dié tussen die Middeleeue en die moderne tyd (kyk Kok \& Kok 2010:37). Hieroor het die godsdiensfilosoof van Princeton, Diogenes Allen (1989), bykans twee dekades gelede al opgemerk:

Our intellectual culture is at a major turning point. A massive intellectual revolution is taking place that is perhaps as great as that which marked off the modern world from the Middle Ages. The foundations of the modern world are collapsing and we are entering a postmodern world.

(Allen 1989:2)

Burger (2001:7) en andere soos Smit (1995:9) en Niemandt (2007:25) argumenteer dat veral die Nederduitse Gereformeerde Kerk hom midde-in 'n radikale oorgangstyd bevind en dat ons tans in een van die vinnigste verskuiwings in die mensdom se geskiedenis verkeer (vgl. Niemandt 2007:25). Koopman 
(2002:17) en Steyn (2005:550-559) meen dat daar op die oomblik 'n toenemende gevoel van disoriëntasie en 'n gevolglike moraliteitskrisis onder kerklidmate en veral kerkleiers bestaan (Spangenberg 2003:147). Van der Watt en Kok (2010:1) verwys tereg na navorsing (vgl. Mo Ibrahim Indeks) wat aantoon dat Suid-Afrika statisties gesproke vergelyk met lande wat in oorlog verkeer en dat geweldsmisdade en kriminaliteit geweldig hoog is (vgl. ook Joubert 2008:2). Daar kan dus inderdaad van 'n moraliteitskrisis in Suid-Afrika gepraat word. Ons verkeer in in baie belangrike oorgangstyd waarin sommige selfs praat van reuse uitdagings rondom 'n identiteitskrisis (Steyn 2005:550-559) in die kerk (vgl. Burger 2001:7):

The Dutch Reformed Church finds herself in an identity crisis. Several factors can be identified that gave rise to this situation, such as a new era of democracy and post-apartheid, the autonomy of congregations and the labour law, the so-called New Reformation, charismatic influences, postmodernism, affirmative action and increasing poverty amongst whites, urbanisation and a changing congregational geographical society, extensive social needs, the homosexuality debate, the debate on church re-unification and the confession of Belhar. These factors influenced a number of areas in the Dutch Reformed organism: the perception and understanding of Scripture, the perception of God, the confessions of the church, the liturgy of the church and the ethics of the church.

(Steyn 2005:550)

Die dinamika van oorgangstye moet dus verdiskonteer word indien mens sinvol wil reflekteer oor hoe daar in die konteks van diesulke oorgangstye opgetree moet word.

\section{Die unieke aard van oorgangstye - insigte van Victor Turner}

Om die verskillende fases en tye in die lewe van groepe beter te verstaan, kan ons by die volkekundiges of kulturele antropoloë kers opsteek (Burger 1995:25; Roxburgh 2005). Victor Turner het 'n model ontwerp wat ons kan help om die ontwikkelingsprosesse van geloofsgemeenskappe beter te verstaan. Turner (vgl. Burger 1995 \& Roxburgh 2005) maak die onderskeid tussen 'n societassituasie en 'n communitas-situasie. Die lewensgevoel in hierdie twee situasies verskil hemelsbreed van mekaar. 'n Mens kan die twee situasies saamvat volgens die vergelyking in Tabel 1 (Burger 1995:28).

Hierdie oorgang van societas na communitas ontwikkel volgens Turner (1974:23-59) en, Kok en Kok (2010:38-39) in vier fases:

1. afbreek moment van die societas

2. die werklike krisis

3. die lang herrangskikkingsfase

4. die herintegrasie-fase.

\section{Die afbreek moment van die societas}

'Die wêreld is tans in transito.' Die societas-tyd van die modernisme maak vinnig plek vir die communitas-tyd van die postmodernisme. Die sekulêre film The Matrix is 'n goeie voorbeeld van die polimorfiese integrale konseptering van die wêreld in die postmodernisme. Die modernisme met sy klem op die rede, objektiewe waarhede en die oordrewe optimisme van die antroposentriese mens is besig om plek te maak vir die postmodernisme met sy wantroue in magsisteme en universeel geldende objektiewe waarhede (Johnston 2001:27-28). Konsepte soos differensiasie, pluralisme en skeptisisme is eie aan die nuwe paradigma (vgl. Niemandt 2007:16-26). Die wêreld het in baie opsigte in $\mathrm{n}$ wêrelddorpie (global village) ontwikkel (Friedman 2008; Murray 2006). Inligting oor die hele wêreld kan in 'n kort rukkie via die internet versamel word, en ons leef in 'n konteks van kennis-ontploffing. Meer inligting is die laaste 100 jaar die wêreld ingestuur as wat in die voorafgaande menseheugnis in boeke vasgevang is (Joubert 2010:17-18). Verskillende perspektiewe, waarheidsaansprake en sienings oor een element of gebeurtenis lei tot genuanseerde en pluriforme konsepteringsmoontlikhede. Die vraag ontstaan noodwendig na wat dan 'waar', 'eties', 'normatief' en 'reg' is. Die ou modelle van die modernisme wat algemene universele waarhede in 'boksies' geplaas het word nie meer aanvaar nie. Die opkoms van die kwantumfisika wys dat Newtoniaanse wetenskap nie altyd suiwer objektief is nie (Wheatley 2006:xiii; 28, 58, 157). Popper en Kuhn (vgl. Wheatley 2006:147, 201) voer aan dat elke wetenskaplike sy eie subjektiewe voorveronderstelling en paradigma het. Objektiwiteit is 'n mite en waarheid hiervolgens relatief.

\section{Die werklike krisis}

Die Kerk en ander geloofsgemeenskappe staan nie los van die wêreld en dit wat in die wêreld gebeur nie. Dieselfde mense wat in die wêreld werk en leef is gelowiges wat Sondae kerk toe gaan en daagliks met God in verhouding staan (Joubert 2008:1-2). Om dus te beweer dat die kerk nie deur hierdie oorgangstyd geraak gaan word nie, is om onnadenkend met die vraag om te gaan (Niemandt 2007:107).

\section{Die lang herrangskikkingsfase}

Die NG Kerk is tans in 'n radikale oorgangstyd (Steyn 2005:550). Nie net die gebeure in die wêreld nie, maar ook die demokratiseringsproses in Suid-Afrika het ingrypende invloed uitgeoefen op die veranderingsproses (Joubert 2008:1-2). Lidmate in die NG Kerk beleef tans 'n swaai vanaf 'n sterk gestruktureerde societas-situasie na in meer onsekere, ongestruktureerde communitas-tyd (Burger 1995:27; Niemandt 2007:12). Wanneer mens so 'n swaai intens beleef, vind jy dat 'n bepaalde soort lewensoriëntasie skielik nie meer funksioneel is nie (Roxburgh 2010:19-40). Die gevoel van disoriëntasie en 'n oriëntasiekrisis (liminaliteitservaring) is 'n tipiese emosie wat gepaard gaan met die oorbeweeg van 'n societas-situasie na 'n communitas-situasie (Roxburgh 2010:19). Hierdie feit word duidelik indien mens net na die polemiek in die koerante die afgelope paar jare kyk (vgl. Steyn 2005:550; Spangenberg 2003:147, 2004:274-293).

\section{Samevatting}

- Die NG Kerk in Suid-Afrika - in die wêreld - is tans middein 'n radikale oorgangstyd vanaf 'n sterk gestruktureerde societas-tyd met absolute waarhede na 'n communitas-tyd met sy ongestruktureerdheid en skeptisisme.

- Radikale oorgangstye behels 'n gevoel van disoriëntasie en 'n gevolglike oriëntasiekrisis (Roxburgh 2010:19-40; Van der

TABEL 1

'n Vergelyking tussen societas- en communitas-situasies

\begin{tabular}{|c|c|}
\hline Societas & Communitas \\
\hline Voorspoedtyd: Probleme van gemeenskap goed onder beheer gekry. & Oorgangstyd: Onsekerheid word ervaar - dekonstruksie van ou struktuur. \\
\hline $\begin{array}{l}\text { Funksioneer sterk in struktuur: Samelewing is goed georden en beleef ' } n \text { groeifase op } \\
\text { baie gebiede. Oordrewe optimisme word ervaar in menslike vermoëns. Uit geskiedenis } \\
\text { van Bybel: Dawid-era. }\end{array}$ & $\begin{array}{l}\text { Ongestruktureerd, ou strukture werk nie meer nie: Baie vrae, nadenke, } \\
\text { bewustheid van emosie. Uit geskiedenis van Bybel: woestyntyd en ballingskap }\end{array}$ \\
\hline $\begin{array}{l}\text { Heelwat orde en reëls: Sterk institusionalisering. Kry beheer oor samelewing en oor die } \\
\text { lewe. Vaste orde en duidelike struktuur. }\end{array}$ & $\begin{array}{l}\text { Min vaste reëls: Societas se beginsels, reëls en orde word sterk bevraagteken. } \\
\text { Herrangskikking van verhoudings, reëls, ordes en gedragskodes. }\end{array}$ \\
\hline $\begin{array}{l}\text { Fokus op rolle en funksies: Mense aangestel vir bepaalde funksies met duidelike rolle. } \\
\text { Word netwerk van stelsels. Burokrasie figureer goed. }\end{array}$ & $\begin{array}{l}\text { Fokus op mense en verhoudings: Ongeregtigheid van struktuur ontbloot. Geborgenheid } \\
\text { in struktuur gesoek in verdiepte menseverhoudings. }\end{array}$ \\
\hline Hiërargie van status geld: Jou posisie in die struktuur bepaal jou status en mag. & Groter gelykheid tussen mense: Noodwendige gevolg as struktuur val. \\
\hline $\begin{array}{l}\text { Lewensgevoel van geborgenheid: Ervaar geborgenheid in die sekuriteite van die } \\
\text { struktuur se orde. }\end{array}$ & $\begin{array}{l}\text { Lewensge voel van onsekerheid: Vra na wat is 'waarheid', watter rigting ingeslaan moet } \\
\text { word, disoriëntasie. }\end{array}$ \\
\hline
\end{tabular}


Watt 2002:169). Koopman (2002) en andere meen dat ons tans 'n morele oriëntasiekrisis beleef. Burger (2001) en Steyn (2005) meen dat die NG Kerk 'n identiteitskrisis beleef.

- Die liminaliteitservaring van die oorgangstyd vereis volgens Roxburgh (2010) deeglike refleksie en nadenke. Burger (2001) betoog vir die (her)ontdekking van ons gereformeerde tradisie, vanaf ons wortels na visionêre en missionêre leierskap (Niemandt 2007:108; Roxburgh 2010:196). Indien ons nalaat om in die communitas-tyd deeglike refleksie te doen, gaan daar nie genoegsame diepte in die nuwe societastyd wees nie.

- Teen die agtergrond van grootskaalse verandering is dit dus noodsaaklik dat ons deeglike refleksie doen oor die plek en die rol van die etiek en die belydenis in die prediking, teen die agtergrond van die oorgangstyd en die liminaliteitservaring van die nuwe communitas-situasie (Van der Watt 2005:247-259).

\section{DIE ROL VAN DIE KERKLIKE BELYDENIS IN DIE PREDIKING}

In hierdie deel is daar gepoog word om te besin oor die rol wat die kerklike belydenis in die prediking behoort te speel, aangesien belydenis en etiek nou verwant aan mekaar is. Die belydenis kan inderwaarheid as die voorveronderstelling van die etiek beskou word.

\section{Die rol wat die kerklike belydenis in die kerugma behoort te speel}

Vanweë die historisiteit van die mens se verstaan word sy geskiedenis gekenmerk deur die 'opeenvolging van kultuurhistoriese tydperke wat elkeen 'n eie konstellasie van verstaansonderstellinge het' (Joubert 2008; Wethmar 1977; Wheatley 2006). Dit bring mee dat daar op 'n bepaalde oomblik iets soos 'n identiteitskrisis in die Christendom of in 'n kerk kan ontstaan (Steyn 2005:205). Dit is juis hier waar die morfologies integrale begrip dogma ${ }^{1}$ help om die Christelike boodskap verstaanbaar te maak in die nuwe verstaanshorison waarin ons tans verkeer. Myns insiens kan die kerklike belydenis 'n belangrike rol speel in die bewaring van die kontinuïteit en identiteit van die wesenlik Christelik-Gereformeerde selfverstaan en die gevolglike etiese dimensie wat daaruit voortvloei (vgl. ook Joubert 2008 \& Van der Watt 2005).

\section{Die verhouding tussen Skrif, belydenis en prediking}

In my ervaring as gemeenteleraar en akademikus het ek dikwels ervaar dat bepaalde gemeentelede negatiewe gevoelens en reaksie toon teen enige vorm van leerstelligheid. Dit is veral in die konteks van jeugbediening waar te neem. Jongmense word nie net groot in 'n pluriforme en paradoksale wêreld nie (Niemandt 2007:26-27), maar is ook gemaklik met teenstrydighede en onsekerheid. Dit is egter kenmerkend van die ongestruktureerde communitas-situasie en die onsekerheid en skeptisisme van die postmoderne tyd. Die vraag is steeds wat die plek van die belydenisdimensie in die kerk en prediking moet wees, of wat die verhouding tussen die explicatio en applicatio daarvan moet wees (Cilliers 2003:20).

Wethmar (2003) argumenteer dat die Reformatoriese kerk op die Woord berus (vgl. sola scriptura). Die Woord van God het 'n inhoud - dit is nie net die vertolking van een of ander emosionele aandoening nie. Luther het immers gesê: 'Hef die leerstellige uitsprake op, en jy het die Christendom opgehef.' Die denotatiewe belydenisdimensie van die reformatoriese kerk is niks minder nie as die wyse waarop die Skrif haar gesag laat geld in kultuurhistoriese omstandighede wat verskil van dié waarin die Bybel

1.As bewuste verteenwoordiger van 'n Reformatoriese teologie kies ek in lyn met Ebeling (1967:80) vir die term belydenis (confessio, homologia) om die kerklike Ebeling (1967:80) vir die ter belydis). (c) leer aan te dul (vgl. ook term dogma in ' van die oorsprong en ontwikkeling van die term dogma kan Wethmar (1977:25vv) geraadpleeg word. tot stand gekom het nie. Daarmee word Skrif en belydenis nie met mekaar gelykgestel nie. Wethmar (2003) argumenteer verder dat die verhouding tussen Skrif en belydenis ten diepste daarin lê dat die belydenis uitvoering gee aan die gesag van die Skrif, soos 'n pianis uitvoering gee aan die teoretiese musiekstuk voor hom. Daarom staan Skrif en belydenis vanuit die Gereformeerde siening daarvan nie in spanning tot mekaar nie. Die subjek van die belydenis is die kerk en nie ' $\mathrm{n}$ individu nie. Die belydenis is ten diepste' $n$ geestelike gebeure (Pieterse 2005). Luther en Calvyn het gesê die Skrif het gesag as 'Skrif in aksie', as 'verkondigde Woord'. Hiermee korrespondeer die sola fidei. Die Skrif wek die geloof - waardeur ons sola gratia ontvang - wat alles saamgevat kan word in die Christus alleen. Met ander woorde, die Skrif en die belydenis gee ten diepste uitdrukking aan die gesag van Christus (vgl. Joubert 2008). Dit is presies waaroor dit in die prediking en die belydenis behoort te gaan. Die uitdaging in prediking is dus om só te preek dat die karakter en intensie van die Skrif na vore kom (Cilliers 2003:20). Hiervolgens is die Skrif, die belydenis, die prediking en die teologie verskillende 'hiërargiese' gestaltes van die Woord van God. Die Skrif is egter altyd meerwaardig, genuanseerd en vol verrassings, soos die kreatiewe lees daarvan op grond van nuwe verstaanshorisonne ons tereg geleer het.

Dit is dan juis hier waar die groot probleem ter sprake kom wat ons kan noem: die fenomeen van die dogmatiese as hermeneutiese probleem, of anders gestel, die probleem van die verhouding tussen dogma en verstaanshorison ${ }^{2}$. Hierdie saak het ingrypende implikasies vir die kerk se sendingopdrag waar sy voor die taak te staan kom om die kerklike leer te vertaal in telkens nuwe verstaansvooronderstellinge (Wethmar 1977:15; vgl. Sweet \& Viola 2010:xvii). Alvorens ons die rol van die kerklike belydenis in die prediking kan bepaal, is dit nodig dat ons dus eers besin oor die verhouding tussen belydenis en kerugma (vgl. Cilliers 2003:20-28). McGrath (1990) verwys na belydenis as ' $\mathrm{n}$ 'integrative concept'. Hy bedoel daarmee dat die konsep belydenis'n komplekse begrip is en 'n verskeidenheid van gegewens bevat en as't ware in balans hou: dit is ' $\mathrm{n}$ homologie en 'n credo, dit is beslissing en inhoud, menslike belydenis maar geestelike gebeure en openbaring, en terselfdertyd het dit 'n afgrensende identiteitvormende dimensie (Campbell 2008:64$68)$

Die nuutste verwikkelinge in eksegese en hermeneutiek (vgl. Du Toit 2009:13-105; Kok \& Kok 2010) toon aan dat die verband tussen Skrif en belydenis in die verlede te maklik beskou is as dat die eksegeet en spesialisprediker deur middel van 'korrekte eksegese' en gesofistikeerde histories-kritiese metodologie die teks se (enkele) ware betekenis kan ontsluit (Cilliers 2003:21; Lategan 2009:13-105; Long 1990:342-343). 'n Konglomeraat van diverse metodologieë met hul eie ideologiese voorveronderstellings veroorsaak deesdae dat die pad tussen Skrif en kerugma, of Skrif en belydenis of leer nie meer so maklik te vinde is nie (Cilliers 2003:21; Du Toit 2009:90-103; Long 1990:342-343). Tweedens het daar in die laaste paar dekades 'n veranderende perspektief ingetree rakende die siening van Skrifgesag. Hiervolgens word die Bybel beskou as God se woord, maar God se woord in en deur menslike taal - geskryf deur mense wat onlosmaaklik verbind was aan 'n bepaalde sosio-kulturele konteks en die Jesusgebeure en Godsgebeure interpreterend weergee. Cilliers (2003:23) merk tereg op dat dit impliseer dat die Bybel - indien ons dit op ' $n$ verantwoordelike wyse wil lees - met behulp van historiese en linguistiese wetenskappe bestudeer behóórt te word, wetenskappe waarin onder meer gevra word na die sosiale agtergronde van die Bybel (die sogenaamde wêreld agter die teks), die literêre aard van die teks self (die wêreld in die teks), asook die werkings- en vertolkingsgeskiedenis van die teks (die wêreld voor die teks).

Die belydenis is finaal en voorlopig: Die kerklike belydenis is altyd finaal en voorlopig (Wethmar 1977:267, 2003), en dikwels sterk sosiaal-histories kontekstueel bepaald (vgl. Belhar 1986). As ons met ander woorde argumenteer die belydenis

2.Hierdie komplekse saak word volledig bespreek deur Conrad Wethmar (1977) in sy boek Dogma en verstaanshorison. 
is die gestalte waarin die gesag van die Skrif tot uitdrukking behoort te kom, beteken dit dat die belydenis die gebeure is waarin my geloof hom uitspreek (Pieterse 2005). In hierdie sin is die belydenis finaal. Ek wat die belydenis uitspreek is egter wesenlik subjektiewe (sondaar) mens wat oor God - die gans Andere - praat, en dit binne 'n bepaalde konteks. Augustinus het gesê God is altyd groter as menslike woorde en oortuigings. In hierdie opsig is die belydenis altyd voorlopig. Daarom gaan belydenis altyd met gebed gepaard sodat ons spreke aan God reg doen. Daarom is spreke oor God net sinvol as dit gepaard gaan met spreke met God (lex orandi est lex credendi) (Cilliers 2004:198).

In Matteus 16:13-20 sien ons die eerste belangrike elemente van 'n geloofsbelydenis in die Skrif (Sweet \& Viola 2010:xvii). Om bloot teoreties oor God te praat, laat nie reg daaraan geskied nie (Burridge 2007:218-224). Jesus sê vir Simon: 'Gelukkig is jy, Simon Barjona, want dit is nie ' $\mathrm{n}$ mens wat dit aan jou geopenbaar het nie, maar my Vader wat in die hemel is.' Net so in Johannes 20:28. Nadat Thomas van die ander dissipels gehoor het dat Jesus opgestaan het en aan hulle verskyn het, het hy luidkeels sy twyfel uitgespreek en gesê: 'As ek nie die merk(e) van die spykers aan sy hande sien en my eie vingers daarin steek nie - sal ek nooit glo nie' (my vertaling van die Griekse bronteks). Ongeveer'n week later was die dissipels weer bymekaar agter geslote deure. Skielik het die verrese Jesus aan hulle verskyn en Hy het hom aan die ongelowige, twyfelende Thomas geopenbaar en hom uitgenooi om aan die merke op sy lyf te raak. Die volgende oomblik transformeer die twyfel en ongeloof van Thomas en bely hy die kulminerende belydenis in die evangelie volgens Johannes: 'My Here en my God' (Kok 2009:112-147). Volgens Johannes (vgl. Joh 3:3-8; kyk Kok 2008) en Paulus (Gal 1:11-12) word die belydenis dat Jesus Here is sterk verbind aan die openbaringsdimensie waarin God of die Gees telkens as die primêre handelende subjek voorgestel word (vgl. die aoristus passief-konstruksie in Gal 1:12).

Vanuit die Gereformeerde belydenisperspektief word aanvaar dat waar ' $n$ belydenis tot stand kom dit nie blote teorieë is nie, daar vind openbaring plaas en daarom is dit niks minder nie as in geestelike gebeurtenis (kyk Ridderbos 1997:44). Anders gestel: 'n Belydenis is alleen 'n geestelike gebeurtenis as dit 'n produk van openbaring is (Cilliers 2004:198-199). In Johannes 20:29 merk die Johannese Jesus egter op dat Thomas se geloof die resultaat is van die feit dat hy gesien het, maar dat die wat nie gesien het nie en tog glo, diegene is wat waarlik salig is. Dié wat nie sien nie, maar tog glo, kan tog alleen tot geloof kom op grond van die woorde van dié wat oor Jesus getuig. Daarom kan daar geargumenteer word dat die oorgelewerde tradisie - die verkondigde evangelie - uiteindelik onlosmaaklik verbind word met die belydenisdimensie van die Christelike geloofsgemeenskap en dat dit nou saamhang met die missionêre dimensie van die kerk (Niemandt 2007:108). Anders gestel: Sonder die belydenisdimensie is daar geen ware missionêre dimensie moontlik nie. Die bedoeling en intensie van die Skrifgetuienis het dus 'n duidelike openbaringsdimensie en 'n missionêre dimensie. Die Nuwe Testamentiese Bybelskrywers lê nie net klem op die feit dat dit wat in die Jesusgebeure plaasgevind het ' $n$ inkarnerings- en openbaringsdimensie bevat nie (vgl. Joh 1:18), maar ook dat dit deel vorm van die missio Dei (Bosch 1991; Kok \& Niemandt 2009), of God se groot missionêre plan teen die agtergrond van die soteriologie. In die geskiedenis van die dogmabegrip speel Romeine 10:9-10 'n belangrike rol:

As jy met jou mond bely dat Jesus die Here is, en met jou hart glo dat God Hom uit die dood opgewek het, sal jy gered word. Met die hart glo ons, en ons word vrygespreek; en met die mond bely ons, en ons word gered.

Van die vroegste tye af is daar duidelik onderskei tussen twee kategorieë van belydenis: om met jou mond te bely (homologia) en met jou hart te glo (credo). In 'n belydenis sit daar twee elemente wat later in die dogmatiek weergegee word met die terme: fidei historica en fidei salvifica. Dit kom neer op twee tipes geloof: historiese geloof en reddende geloof. Historiese geloof beteken ek neem kennis daarvan dat Jesus geleef het, maar dit maak my nie 'n wedergebore gelowige nie. In reddende geloof is daar ' $n$ performatiewe taalgebruik. Ek maak nie alleen 'n stelling nie, maar ek maak dit van so 'n aard dat ek my optrede daaraan bind (etiese dimensie) (Wethmar 2003). Die woord word met ander woorde 'n gebeure (Pieterse 2005:409-422).

Die Griekse woord dogma het onder meer twee latente betekenismoontlikhede:

- dit lyk so

- ek dink dit is so.

Dit kan die betekenis dra van opinie, oortuiging of filosofie van 'n bepaalde geloofsgemeenskap. In die derde en die vierde eeu is daar alreeds gepraat van die leer van die kerk as die filosofie van die Christene (Wethmar 2003). In 'n baie vroeë stadium van die Kerk se geskiedenis het daar 'n verintellektualisering van die geloofsbegrip ontstaan. Die geloof is egter veel meer as $n$ blote stel kognitiewe proposisies. Die dimensie van dogma se 'dit lyk vir my so' dra die betekenisnuanse van 'n konkrete performatiewe besluit. Sodra so 'n besluit een word van die kollektiewe geloofsgemeenskap, word dit gestruktureer in 'n juridiese sin van die woord. Hier word die leer van die kerk 'n wet wat nie verstaan of geglo wil word nie, maar gewoon gehoorsaam moet word. As dogma net kennis word, word die geloof net kennis en wesenlik verbeeldingloos (Cilliers 2004:95). As dogma wet word, word geloof net gehoorsaamheid (Wethmar 2003). Die gevolg daarvan is te bespeur in die Rooms Katolieke Kerk in die wyse waarop hermeneutiese probleme op 'n juridiese manier opgevang word. Dit is juis hier waar die woord dogma'n negatiewe betekenis begin kry. So het dit gebeur dat die term dogma enersyds gelei het tot 'n verintellektualisering en verjuridisering van die geloof.

Wethmar (1977:266; 2003) wys tereg daarop dat daar teen die volgende ekstreme gewaak moet word:

- Die verabsolutering van die dogma soos in die nareformatoriese ortodoksie waar die dogma in die kerugma opgeneem word.

- Die skeiding van dogma en kerugma soos in die neoprotestantse dogmageskiedskrywing.

Die kategorie van die hermeneuties-dogmatiese impliseer dat die kerugma en dogma onderskei maar nie geskei mag word nie. Dogma en kerugma is met ander woorde twee dimensies van dieselfde gebeure. Die dogma is die 'aangekomenheids- en stabiliteitsdimensie in die geskied van Gods Woord, terwyl die verkondiging die gebeurlikheidsdimensie daarvan is' (Wethmar 1977:270). Indien mens terugbeweeg na die 'oorsprong van dogma' is dit duidelik dat die belydenis die 'oervorm' van die latere dogma was. Die grondvorm van die belydenis word ten diepste gekenmerk deur inherente grondvorme soos gebed, getuienis, doksologie en leer as wesenlik tot die belydenis. Daarom kan ons sê dat die dogma in sy oorspronklike vorm 'n morfologies integrale geloofsuitspraak was (Wethmar 1977:266). In die dogma laat die Skrif sy gesag dus op in dinamiese hermeneutiese wyse geld. In die dogma neem die Skrifboodskap in gestalte aan wat bepaal word deur die aktuele verstaanshorison van die tyd.

In die hedendaagse konteks met sy oordrewe klem op die praxis, gebeur dit bykans noodwendig dat daar 'n spanning tussen dogma (explicatio) en praxis (applicatio) ontstaan (Cilliers 2003:20). Volgens Wethmar (2003) kan hierdie probleem opgelos word deur die Reformatoriese klem dat dit in die dogma ten diepste gaan om die lof ( $\delta \dot{\xi} \xi \alpha$ [doksa]) aan God. Dit gaan nie net daarom dat ek intellektuele korrekte dinge sê nie, maar dat ek die intellektueel korrekte só sê dat God daardeur geëer word. Dogma moet uitdrukking gee aan ons verhouding met God. Die leer funksioneer ten diepste om reg oor God te praat. Daar word alleen reg oor God gepraat as mens met God praat. Daarom kan ons sê dat belydenis wesenlik'n geloofsgebeurtenis en gebed is. Die dogma of kerklike leer kan egter misbruik word om die betekenis van 'n wet te gee. Dit is hier waar predikers die kerklike leer of tradisie as wet gebruik en die geloof tot wet reduseer (Cilliers 2004:84). Die wese van die dogma as openbaringsgebeure en gebed tot God maak die leer nie tot wet wat gehoorsaam moet word nie, maar tot innerlike oriëntasie 
waar daar ten diepste voor die aangesig van God geleef word in 'n lewe as 'n gebed tot lof van God. Die negatiewe energie van die hedendaagse spanning tussen dogma en praxis of dogma en geloof kan positief-energerend getransformeer word as ons verstaan dat dit in die kerklike leer ten diepste gaan om die lof van God in gebed deur 'n innerlike geloofsoriëntasie as gevolg van die lewewekkende krag van die Heilige Gees in en deur die Woord. ${ }^{3}$ So kan ons keer dat die leer van die kerk verwaarloos word of om die verkeerde redes aanvaar word. In die ongestruktureerde communitas-tyd wat gekenmerk word deur nuwe verstaanshorisonne en gevolglike disoriëntasie (Burger 2001:7) kan die kerklike leer ons dus help om ons te heroriënteer ten opsigte van die herontdekking van ons gereformeerde (wesenlik Christelike) identiteit en die gevolglike performatiefetiese dimensie wat daaruit voortspruit.

\section{DIE ROL VAN DIE ETIEK IN DIE PREDIKING}

Onder hierdie subtema is besin oor wat die teologies verantwoorde manier is om morele kwessies in die prediking aan die orde te stel en moralisme te vermy.

\section{Aktualiteit van die tema}

Ons het reeds hier bo daarop gewys dat die wêreld en die kerk in die wêreld tans in 'n radikale oorgangstyd verkeer: vanaf 'n sterk gestruktureerde societas-situasie na 'n ongestruktureerde, onsekere communitas-situasie. Coenie Burger (2001:7) en andere soos Arnold Smit (1995:9) en Gert Steyn (2005) argumenteer dat veral die NG Kerk hom midde-in 'n radikale oorgangstyd bevind en ander soos Koopman (2002:17) meen dat daar tans 'n toenemende gevoel van disoriëntasie, en 'n gevolglike moraliteitskrisis, onder kerklidmate en veral kerkleiers bestaan. Vooraf gemelde skrywers is dit eens dat mense in tye van radikale omwentelings soek na duidelike aanwysers, wat die vraag na moraliteit en etiek sterk na vore laat kom. Burger (2001) en Koopman (2002) toon oortuigend aan dat ons opnuut sekere perspektiewe vanuit die rykdom van ons Christelikgereformeerde tradisie moet (her)ontgin en ons identiteit daarvolgens her-oriënteer.

Johan Cilliers $(1998,2000,2003,2004)$ wys op empiriese navorsing in die veranderingstye rondom 1994 tot 1995 in verband met preke in verskeie kerke. Die interessante bevindinge wys daarop

\footnotetext{
3.Die vraag kan tereg gevra word: Kan en behoort geloofsleer dan gepreek te word? Spoelstra (1991:375) argumenteer dat '[w]ie geloofsleer as 'n teoretiese intellektuele aktiwiteit beskou en wie geloofsleer as weergawe van Godsopenbaring nie maar as Calvyn was die geloof baie prakties (Burger 2001:98). Ons refleksie staan in diens van God se openbaring, gerig op die praktyk van die geloofslewe sodat ons God se wil kan verstaan en dit Coram Deo uitleef (Burger 2001:98). 'n Belydenis as gestalte van die Woord en antwoord op die openbaring van God, in gebed gebore deur die gemeenskap van gelowiges roep om die kerugmatiese verbalisering daarvan, waar dit Woord-in-aksie word. Volgens 1 Korintiërs. 12.3 'kan niemand sê (bely) dat Jus die Here is nie, behalue deur die Hilige Ges'. Die aanvaarding van die dat Jesus die Here is nie, behalwe deur die Heilige Gees'. Die aanvaarding van die kerugma is wat in die Nuwe Testament 'geloof' genoem word (Wethmar 1977:97) 'Die openbaring roep die geloof op' (Wethmar 1977:97). Volgens Romeine 10:9 is die geloof en belydenis ten nouste verbonde aan mekaar. Dit wat geopenbaar word en deur die prediking oorgelewer word, is wesenlik die inhoud van die geloof. Die kategismus as belydenis voeg niks by tot die Woord nie. Dogma en kerugma is twee dimensies van dieselfde gebeure (Wethmar 1977:270). Die dogma is die 'aangekomenheids- en stabiliteitsdimensie in die geskied van Gods Woord terwyl die verkondiging die gebeurlikheidsdimensie daarvan is' (Wethmar 1977:270). Die kerklike prediking is ' $\mathrm{n}$ verdere ontplooiing, uitleg en toepassing van wat implisiet in die belydenis, in die Woord, gegee is. Die belydenis word gekenmerk deur ' in de openbaarheidsteenoor God of die naaste uitgespreek te word: 'Met die akklamatoriese faset van die belydenis, val ook die liturgiese en die doksologiese funksie daarvan saam' (Wethmar 1977:100). Die doksologiese element van die belydenis is wesenlik belangrik. Dit gaan in die eerste plek om die lof en eer van God. Die proklamasie is ook ' $\mathrm{n}$ belangrike element van die belydenis. Waar Jesus as Heer erken word, ontstaan 'n noodwendige missionêre aktiwiteit (Wethmar 1977:101). Die kategismus as belydenis is geen dergelike teoretiese uitspraak nie, maar het ' $\mathrm{n}$ performatiewe, bindende karakter op die gelowige. Die Heidelbergse Kategismus as geloofsleer kan dus teoreties gesproke gepreek word, mits dit as morfologies integrale begrip (openbaring lof, gebed, ens.) beskou word en dit nie gereduseer word tot juridiese (openbaring lo, gebed, ens.) beskou word en dit nie gereduseer word tot juridiese wet wat die geloof tot gehoorsaamheid beperk nie. Die groot vraag is of die predike by die kategismuspreek die universele uit en lewer 'n kollektiewe gemeentelike respons op die openbaring van God.
}

dat preke op die kansels in Suid-Afrika 'n sterk moralistiese inslag het, en nie daarin slaag om die evangelie van vrye genade te verkondig nie. Hiervolgens is dit Cilliers en andere se mening dat $90 \%$ van alle preke nie daarin slaag om die evangelie as 'n $\mathrm{krag}$ tot verandering betreffende die konkrete situasie te laat kommunikeer nie (Cilliers 1996:3). Onder moralistiese inslag verstaan Cilliers (1996):

(D)ie opvallende neiging by predikers om uitsluitlik op die innerlike toestand van die hoorders te konsentreer en dan in lyn hiermee luisteraars op te roep om op grond van hulle veronderstelde menslike of godsdienstige potensiaal iets (meer) te doen, beter te vaar, 'ten einde verlos te word'...

(Cilliers 1996:3)

Wettisisme is springlewendig op die kansels van ons land (Cilliers 1996:4). Dit kom neer op 'n misverstaan van die verhouding tussen wet en evangelie (Cilliers 1996:5, 9). Cilliers (1996) beskryf wettiese prediking as volg:

Wettiese preke neem die sonde en dus die onvermoë van die mense om die wêreld en hulself te verander, nie ernstig op nie ... [O]ok neem dit nie die vermoë van die evangelie en dus die krag van God se genade ernstig op nie!

(Cilliers 1996:7)

Die Bybel is nie 'n moralistiese handboek nie (Cilliers 2004:2). Sommige predikers gebruik dit as een of ander bron van illustrasies in tipies eksemplariese prediking: met sedelessies, moralistiese toepassings, heldefigure, en dies meer (Cilliers 2004: 115-117, 163, 171). Dit kan so maklik lei tot morele fundamentalisme, kleinburgerlikheid en bekrompe wettisisme (Burger, Müller \& Smit 1996:11). In die lig hiervan is dit dus nodig om te besin oor wat ' $\mathrm{n}$ teologies verantwoorde wyse is om morele kwessies in die prediking aan die orde te stel en moralisme te vermy, asook om 'n meer uitgebreide perspektief op byvoorbeeld Nuwe Testamentiese etiek te ontwikkel.

\section{Nuwe verwikkelinge in Nuwe Testamentiese Etiek}

Die pad van die Skrif na die bestemming van die bepaling van die etiek het in die laaste paar jaar dramatiese groei ondergaan. Die Nuwe Testamentikus Ruben Zimmermann het onlangs (vgl. Zimmermann 2009, 2010) geargumenteer dat die klassieke Bultmaniaanse onderskeiding tussen die indikatief en die imperatief nie meer voldoende is nie, en dat daar jenzeits von indikativ und imperativ [na die anderkant van indikatief en imperatief] beweeg moet word, na die implisiete etiek in die Nuwe Testament. In die literatuurstudie sal die oplettende navorser spoedig verneem dat die terme etiek en moraliteit dikwels as sinonieme gebruik word (vgl. Meeks 1993:3 moraliteit; Wolter 2009:121 - etiek), en dat die navorser eers sy of haar verstaan van die verhouding tussen etiek, etos en moraliteit moet beskryf. Alvorens ons dus oor die rol van die etiek in die prediking kan besin, moet daar eers bepaal word wat met die terme bedoel word, en wat met die nuwere implisiete etiese perspektiewe bedoel word.

Dit is ook duidelik dat die meeste praktiese teologiese studies nie die nuwere ontwikkelinge in die Bybelse wetenskappe verdiskonteer nie, en dikwels nog met die klassieke indikatiefimperatief struktuur werk (vgl. Cilliers 2004), of met 'n oorvereenvoudigde hermeneutiese metodologie werk (vgl. Burger 1996:21). Burger (1996:21) merk byvoorbeeld op dat die Woord van God altyd twee kante het: dit wil informeer maar ook transformeer (Luther: sermo dei venit mutaturus; vgl. Cilliers 2003:24). Die Gees werk vervolgens die transformasie in ons lewens deur die: skenkende (Zuspruch), onthullende (Widerspruch) en eisende (Anspruch) funksies van die Woord. Burger (1996) verduidelik dit verder aan die hand van die volgende metaforiese beelde:

Die woord wil die volgende drie goed vir ons wees: $n$ Hand wat aan ons iets wil skenk, in spiël wat aan ons sekere aspekte wil openbaar, en in deur wat ons optrede bind sodra ons deurgestap het. (Burger 1996:21) 
TABEL 2

'n Hermeneutiese model vir Evangelieprediking

\begin{tabular}{|c|c|c|}
\hline Wat wil die teks skenk? & Wat wil die teks onthul & Wat eis die teks \\
\hline $\begin{array}{l}\text { 1. Wat sê die teks oor God se wese en werk - wat wil } \\
\text { Hy doen en gee? }\end{array}$ & $\begin{array}{l}\text { 1. Wat sê die teks oor die effek van sonde? (Sien die } \\
\text { fundamentele probleem - spieël-funksie.) }\end{array}$ & $\begin{array}{l}\text { 1. Teks 'gee' en 'onthul' nie net nie - dit vra iets van ons, } \\
\text { maak aanspraak op ons eis om gehoorsaamheid. } \\
\text { Imperatiewe van die teks. }\end{array}$ \\
\hline 2. Wat is die indikatiewe wat die imperatiewe voorafgaan? & $\begin{array}{l}\text { 2. Identifiseer fundamentele probleem wat onthul word - } \\
\text { sien hoe hand van God antwoord op probleem skenk. }\end{array}$ & $\begin{array}{l}\text { 2. Gehoorsaamheid neem dit wat geskenk is in besit - alleen } \\
\text { so kry ons deel aan die genadegawes. }\end{array}$ \\
\hline
\end{tabular}

Wanneer mens oor die deugde preek kan mens hierdie drie funksies na die eksegese (informatief) gebruik om die performatiewe of transformerende kant daarvan te belig:

Bogenoemde hermeneutiese model vir evangelieprediking is 'n handige model, maar is myns insiens 'n oorvereenvoudigde model wat nie die implisiete dimensies van die etiek in die Nuwe Testament verdiskonteer nie. Dit werk wesenlik nog met die gedateerde Bultmaniaanse indikatief ('wat wil die teks skenk'-imperatief en 'wat eis die teks'-struktuur). Zimmermann (2009a, 2009b \& 2010) bied 'n nuwere perspektief vanuit die bybelwetenskappe wat die praktiese teologiese besinning tot diens kan wees.

Volgens Zimmermann (2009a:399) kan 'etiek' gedefinieer word as die sistematies-teoretiese ondersoeking van 'n geleefde etos. Wolter (2009:121) merk op dat Aristoteles (vgl. Analyt. Post 1,33 [89b9]) reeds die etiek as 'ein Theorieunternehmen gekenzeichnet, das zur Philosophie gehört' [Die etiek as ' $\mathrm{n}$ teoretiese en veral filosofiese instansie]. Aristoteles het in sy werk 'n sistematiese refleksie van die waardes en motiewe van bepaalde gedrag gemaak. Volgens die klassieke Aristoteliaanse etiek het 'etiek' te maak met die rasionele analise van morele waardes, die kritiese evaluering van etos en 'n bevraagtekening van die motiewe van moraliteit (Zimmermann 2009a:400). Hiervolgens is dit dus duidelik dat 'n (Christelike) teologies-etiese besinning oor die rol van die etiek in die prediking 'n tweede-orde aktiwiteit verteenwoordig, waarin die logika van die morele diskoers in 'n bepaalde konteks ondersoek behoort te word. Volgens Pieper (2000:24-30) word etiek dus beskou as die 'wetenskap van morele aksie' en in die woorde van Zimmermann (2009a:400) niks minder nie as die '[systematic] reflexivity on the moral judgements and actions of people in die scope of the Christian belief.'

Die groot vraag wat vervolgens uit laasgenoemde voortspruit is of mens dan enigsins van 'etiek' of van 'etiese teorie' in die Nuwe Testament kan praat? Tegnies gesproke, binne die dampkring van 'n antieke Aristoteliaanse definisie van etiek, is daar baie min 'sistematies refleksiewe, eties-teoretiese' materiaal in die Nuwe Testamentiese geskrifte. Die Nuwe Testament bevat eerder kontekstuele geleentheidsgebaseerde geskrifte tussen 'n skrywer en sy gehoor (Zimmermann 2009a:400). Beteken dit dan dat 'n bestudering van die etiek van die Nuwe Testamentiese geskrifte nie haalbaar is nie? Allermins. Ten einde die implisiete etiese dimensies te analiseer moet daar egter na die konteks en die Umwelt gekyk word - met ander woorde na die etos (gebruike en konvensies) agter die teks, en die waardes wat binne die konteks van die oorspronklike gehoor bestaan het. Zimmermann (2009a:401) argumenteer dat alhoewel daar nie 'n sistematiese sinopsis van meta-refleksies aangaande norme en waardes in die Nuwe Testamentiese literatuur bestaan nie, dit wel so is dat 'implicit and sometimes explicit reasons as well as the argumentative recourse to certain ethical maxims and norms [that] underlie the individual paranesis'.

In die Pauliniese literatuur byvoorbeeld bestaan daar bepaalde implisiete etiese reëls en waardes wat agter die etos of gedrag veronderstel word en dus 'n bepaalde etos-refleksie en waardeoordeel veronderstel. Die uitdaging is om hierdie implisiete dimensies te verdiskonteer. Die implisiete dimensie van die etiek gaan dus verder as die blote indikatief-imperatief struktuur en vra na die veronderstelde 'reflexivity on ethos [that] takes place within the perspective of value judgements ..., in the scope of a value hierarchy' (Zimmermann 2009a:401). In 1 Tessalonisense 5:21 moedig Paulus sy gehoor aan om alle dinge te toets en die goeie te behou. Hier sien ons dus hoe Paulus die hoorders aanmoedig om hulle etos en aksies te evalueer aan die hand van 'n implisiete waarde-oordeel. Hieruit word dit duidelik waarom die blote indikatief-imperatief dimensies nie reg laat geskied aan die rykdom van implisiete etiese dimensies in die Nuwe Testamentiese tekste nie. Alhoewel die Nuwe Testamentiese skrywers nie 'n gesistematiseerde etiek aanbied nie, is daar steeds 'n implisiete etiese dimensie wat' $n$ hiërargie van waardes en waarde-oordele veronderstel.

Die implisiete waardes en norme, en die gepaardgaande implisiete hiërargies-etiese evaluering daarvan, realiseer in 'n bepaalde Umwelt. Binne hierdie Umwelt bestaan 'n hiërargie van waardes (konteks). Verder bestaan die Nuwe Testamentiese tekste nie in isolasie van ander Christelike en selfs heidensfilosofiese Umwelt-tekste nie, maar kry dit verder betekenis binne 'n bepaalde linguistiese of retoriese bedding (intratekstueel) (vgl. Paulus en die Stoïsyne [intertekstuele dimensies]). Indien die Nuwe Testamentiese implisiete hiërargie van waardes vergelyk word met die waardehiërargie in die heidens-filosofiese Umwelt ontdek ons dat die Nuwe Testamentiese waardes dikwels in 180 grade ommekeer van die waardehiërargie van die antieke konteks verteenwoordig (vgl. Paulus se positiewe beskouing van homself as slaaf van God - Rom 1:1; of Jesus as Kurios teenoor die Keiser [vgl. Powell 2009:35]). Hierin word die implisiete etiek dus ontdek:

Thus, we must look at the tradition and background of these norms. Values in a text do not appear in isolation; rather they are used with argumentations, in comparison to other values or even in a hierarchy of values ... [T] he ethical argumentation that is indeed imbedded in the lived ethos of concrete people and communities.

(Zimmermann 2009a:403)

Zimmermann (2009a:404-416) het die volgende heuristiese stappe geïdentifiseer om bogenoemde implisiete etiese dimensies in die teks wetenskaplik verantwoordelik te ondersoek. Die stappe word egter net hier kortliks beskryf aangesien die artikel se beperktheid nie toelaat dat ons dit in diepte kan bespreek nie (kyk Zimmermann 2009a:404-416).

Die vraag waarop ek hier onder wil ingaan is: Wat gebeur in die proses van dekontekstualisering met bepaalde konteksgebonde etos? Dit handel dus oor die vraag na partikularisme en universalisme. Kan alle etiese implikasies binne die Skrif in alle historiese kontekste net so geld? Hierdie vraag hang ten nouste saam met die verhouding tussen Skrif, etiek en prediking: Hoe sien 'n hermeneuties en eties verantwoordelike wyse om met die gebruik, toepassing en interpretasie van die Bybelse waardes om te gaan daarna uit? Neem byvoorbeeld die etiese dimensie en die rol van die vrou in Paulus se argument dat vrouens hoofbedekkings in die erediens moet dra (vgl. 1 Kor 11) of ondergeskik moet wees aan die man (Ef 5:22,24), wat vandag nie meer as universeel geldend geag word nie. Daarteenoor sal die meeste Christene nog steeds buite-huwelikse seks as immoreel en oneties beskou. Watter kriteria word gebruik om te bepaal watter waardes vandag nog geld en watter waardes vandag nie meer geld nie? Dikwels wil dit voorkom of daar' $n$ idealisering en romantisering van die Bybelse etiek bestaan. Daar is egter in die Bybel implisiete etiese dimensies wat as die skadukant van die Christelike etiek (vgl. Van der Watt 2010) beskou kan word. Van der Watt en Kok (2010) toon aan dat die Johannese gemeenskap 
TABEL 3

Heuristiese stappe van die Implisiete Nuwe Testament Etiek (Zimmermann 2009)

\section{Linguistiese vorm}

Hier word gepoog om die antwoord te vind op die linguistiese vorm waarin die etiese stelling gevind word. Hier word die intratekstuele, intertekstuele en ekstratekstuele vlakke geanaliseer en die wyse waarop die vorm van die teks as draer van die etiese waardes funksioneer (vgl. antieke deugdelyste; nuwe genreteorieë, ens.), en wat die potensiële impak daarvan op die antieke leser sou wees.

\section{Normes en waardes vir aksie}

Hier wentel die vraag om die identifisering

\section{Die morele agent}

Logies-e
motiewe

Die logies-etiese interne struktuur van motiewe word bestudeer in ' $n$ poging om te bepaal waarom ' $n$ bepaalde aksie as moreel goed of sleg beoordeel word. Verder word gevra na watter strategie van argumentasie benut word. So word daar onderskei tussen bv. 'presuppositions' of 'implicatures', met ander woorde dardie 'mplisict, moorde daardie implisiete voorveronderstellings en aspekte an betekenis wat ' $n$ bepaalde rafgaan, alhoewel dit nie direk uitgespel word nie. Die vraag is dus hoe individuele etiek en van normes en waardes vir aksie wat 'n normatiewe verpligting op die individu of groep plaas. Daar kan onderske word tussen algemene morele gebruike, geïnstitusionaliseerde morele wette (soos die Torah) of die morele voorbeeld van sleutelpersone (vgl. Paulus of die presbiter in die Johannese briewe). Daa kan onderskei word tussen formeeltiese beginsels (bv goue reals) etiese beginsels (bv. goue reels) en materieel-etiese waardes soos vryheid en liefde. Or geïdentifiseer wat as implisiete etiese argument dien om sekere etiese sake te argumenteer (bv. God se liefde vir ons wat moet lei tot liefde vir'n vyand).

Geskiedenis van tradisie

Hier wentel die vraag om die identifisering van normes en waardes vir aksie wat 'n normatiewe verpligting op die individu of groep plaas. Daar kan onderske word tussen algemene morele gebruike, geïnstitusionaliseerde morele wette (soos die Torah) of die morele voorbeeld van sleutelpersone (vgl. Paulus of die presbiter in die Johannese briewe). Daa kan onderskei word tussen formeeltiese beginsels (bv. goue rëls) (bve goue reels) en materieelests geïdentifiseer wat as implisiete etiese argument dien om sekere etiese sake te argumenteer (bv. God se liefde vir ons wat moet lei tot liefde vir'n vyand).

\section{Konkrete etos}

Die rol van die morele agent as uitvoerde van die waarde-oordeel, asook die antitipe word bestudeer. Hier word gekyk na hoe die verhouding tussen die morele agent, die groep, die leier en God daarna uitsien, en die invloed wat laasgenoemde op die waarde-oordeelproses uitoefen en iteindelik tot morele optrede behoort te lei. Die vraag is dus hoe individuele
Wat is die konkrete etos wat geleef moet word? Etiese besinning is wesenlik verbind aan etos, of geleefde etiek binne'n bepaald groep. Die noodwendige metodologiese vraag is dan hoe die gekontekstualiseerde etos agter die teks sinvol ondersoek kan word. Die etos konkretiseer op verskillende wyses, onder andere in rituele en gebruike wat binn wat binne groepsverband konkretisee en nou met h identiteitsvormende en id vind Dit vind neerslag in huisreëls (huistafels), opdragte, ens. Die gebruike of gewoontes is dus die draers van bepaalde waardes.

Hiërargie van waardes

Hier word die prioritisering en hiërargie van waardes ondersoek. Alle waardes word nie op dieselfde vlak beskou nie. Waardes word geëvalueer en in verhouding tot mekaar binne ' $n$ hiërargie van waardes uitgebou. In 1 Korintiers 6:12 waar Paulus oor die belangrikheid van vryheid praat, word vryheid egter ondergeskik gestel aan vrye seksuele omgang (1 Kor 6:15-17). Laasgenoemde is dus in 'n hoër hiërargies argumentatiewe is dogiese dampkring argumentatiewe en logiese dampkring ingebed. Dit is daarom moontlik om die in moudeles in 'n morele argument te bepaal en dit op ' $n$ gesistematiseerde wyse uit te druk.

\section{Geadresseerde}

Wie die geadresseerde is, en vir wie die norm geld word bestudeer. Sommige etiese dimensies is nie noodwendig kollektiewe aangeleenthede nie maar individuele situasiegebonde etiek ( $\mathrm{vgl}$. bv. Filem 1). Tog is daar implisiete etiese dimensies en 'n hiërargie van waardes wat 'n universele waarde verdiskonteer en dus vir die Die beloof geld. Die bepaalde gevalvan slawerny is dus ne die kontekstuele waarde-dimensie, maar die waarde van gelykheid is antropologies universeel toepasbaar op die ganse geloofsgemeenskap van alle tye. byvoorbeeld vilifikasie en geweldstaal gebruik het as retoriese tegniek. Buitestaanders en opponente van die Johannese gemeenskap word as kinders van die duiwel (Joh 8:44) en geestelik blind (Joh 9:40-41) getipeer. Binne die konteks van 'n patriargale diadiese groepgeoriënteerde wêreldbeeld word kindskap nie net verbind aan identiteit nie, maar ook aan etos of leefstyl. Die Johannese gemeenskap se vilifikasie-taal verteenwoordig verder, in 'n wêreld van eer en skaamte (vgl. Van Eck \& Kok 2010), 'n degradering van die opponente se eer en kom dus op ' $\mathrm{n}$ vorm van simboliese geweld neer (vgl. Bourdieu 1991; Van der Watt en Kok 2010). Die vraag is dus of hierdie konteksgebonde vilifikasie in die proses van dekontekstualisering steeds eties geregverdig kan word in die konteks van 'n postmoderne wêreldbeeld? Met ander woorde, die implisiete etiese skadukant is wel aanwesig in die Nuwe Testament en die vraag bestaan of dit eties is om dit vandag nog so te gebruik in byvoorbeeld die prediking? Is dit in lyn met evangeliese prediking? Dit is hier waar Zimmermann (2009) se metodologie ons help om die konteks en die intertekstuele dimensies te verdiskonteer en die skadukant van die etiek in Johannes teen die agtergond van die missio Dei te interpreteer. Van der Watt en Kok (2010) toon aan dat die vilifikasie-taal as skadukant van die etiek performatief gesproke met die soteriologie en die missionêre proses verbind kan word en dat dit op etiese vlak geïntegreer kan word binne die dampkring van liefde as primêre motivering. Kortweg kom dit daarop neer dat die ganse Johannese meta-narratief of universele goddelike narratief sentreer om die missio Dei waarvolgens God, gemotiveer deur sy liefde vir 'n gebroke wêreld wat in 'n geestelike doodsbestaan verkeer, sy Seun stuur (Joh 3:16) om 'n herskepping teweeg te bring (Joh 9, 20; kyk Kok 2008:248, 382-384). In Johannes 20:21 stuur die verrese Jesus die dissipels uit in die konteks waar die Heilige Gees uitgestort word met die woorde: 'Net soos die Vader my gestuur het, stuur ek julle ook.' Die volgelinge van Jesus word dus opgeroep om opgeneem te word in die sending van die Seun, wat op sý beurt deur die Vader gestuur is. Die ganse sendingplan word gemotiveer deur liefde en is bedoel om 'n herskepping teweeg te bring wat uiteindelik op die soteriologie uitloop. Teen hierdie agtergrond argumenteer Van der Watt en Kok (2010) dat die gebruik van vilifikasie-taal en die gevolglike skadukant van die etiek in Johannes teen die agtergrond van die missio Dei gesien moet word en dat dit implisiet steeds die hart van die wêreld in gedagte het. Dus, geweldstaal of vilifikasie-taal in Johannes is bedoel om in die konteks van die retoriek van Johannes die buitestaanders tot geloof en 'n nuwe verstaan van identiteit, etiek ${ }^{4}$ en etos te motiveer (vgl. Joh 20:30-31). Tog maak Johannes al vroeg in sy geskrif melding daarvan dat dit die Gees is wat hierdie herskepping bewerkstellig en dat die mens nie die primêre handelende subjek is nie (vgl. Joh 3:3, 6, 8). Die skadukant van die geweldstaal in Johannes het dus 'n ligkant en wil dat dié wat in geestelike doodsbestaan en blindheid verkeer tot die Lig (vgl. Joh 1:4) sal transformeer. Die geweldstaal kan dus in Johannes as evangeliese taal beskou word, aangesien die implisiete etiese dimensie se motivering die liefde is.

\section{Teologie van die prediking}

Vir die Reformatore was alle goeie prediking by uitstek evangeliese prediking. Die prediking funksioneer alleen as heilsmiddel indien dit as evangelieprediking aangebied word. Laasgenoemde verwys na prediking waarin nie in die eerste plek gepraat word oor wat mense moet of kan doen nie, maar oor dit wat God gedoen het en steeds doen ter wille van die redding van sy wêreld (Burger et al. 1996:19). In die prediking vertel ons van die groot dade wat God in die verlede gedoen het (Long 2009). Verder is ons primêr besig met die Woord van God en die evangelie van Jesus Christus. Die inherente verskuilde paradoks bring egter mee dat prediking van die Woord nie noodwendig beteken dat ons die evangelie verstaan wat daarin

4 . In aansluiting by Wolter (2009:120-127) en Van der Watt (2006:v-ix), en elders (Kok $2010 \mathrm{~b}$ ) uitgedruk, word daar onderskei tussen identiteit, etiek en etos: Etos word verstaan as die konkrete lewensstyl (Lebenstil) of geïnstitusionaliseerde gedrag van 'n groep, gebaseer op die etiek van die groep - wat weer verstaan kan word as die reëls waarvolgens die groep of gemeenskap funksioneer. Die etiek (reëls) en die etos (leefstyl/aksies) vloei voort vanuit'n bepaalde verstaan van die identiteit. Wolter (2009:126-127) (vgl. Kok 2010) argumenteer oortuigend dat die etos van 'n groep uit'n kombinasie van inklusiewe en eksklusiewe gebruike bestaan. Die eksklusiewe uit h k. inklusiewe op haar beurt wel ook in die breër samelewing figureer en dus die punt van integrasie in die samelewing tot gevolg kan hê. 
vervat is nie (Burger et al. 1996:19). Indien ons nie die evangelie werklik verstaan nie, verstaan ons uit die aard van die saak ook nie die verhouding tussen wet en evangelie nie. Dit is dan wat Luther bedoel het met wettiese prediking. Die Reformatore se teologie van die prediking sou soos volg opgesom kon word (Burger et al. 1996:19):

- Die mens is nie in staat om uit eie krag die veranderings in sy lewe aan te bring nie. Wettiese prediking begin op grondvlak met die verkeerde veronderstellings.

- Volgens die hart van die evangelie wil die Here self verandering by ons bewerkstellig. Hierdie handeling is begrond, geopenbaar en van stapel gestuur in en deur die werk van Jesus Christus.

- Dit is die Heilige Gees wat hierdie veranderingsbesluit van God tot uitvoering kan bring. Die heilswerk van Christus word verder gedra in die wêreld deur die werk van die Heilige Gees.

- Die Heilige Gees is die een wat mense verander.

Die prediker moet dus in die eerste instansie besef dat daar nie oor morele kwessies gepraat kan word indien dit vanuit ' $\mathrm{n}$ subjektiewe menslike dimensie beskou word nie. Die Heilige Gees is die enigste een wat ware vernuwing en verandering kan bewerkstellig, soos hierbo uit Johannes se evangelie geargumenteer. Ons sal nie evangelies kan preek nie, tensy ons besef dat'n etiese lewe in die eerste plek deel van die werk van die Heilige Gees (heiligmaking) is én die resultaat is van in herskepte identiteit. Indien ons dit nie begryp nie, sal ons prediking steeds meer wetties word.

\section{DIE ROL VAN VERBEELDING IN DIE ETIEK EN PREDIKING}

Walter Brueggemann (1995:167-188) en Thomas Long (2009) het ons gewys op die belangrike rol van verbeelding (vgl. ook Cilliers 2004:94) in die verkondiging van die kerk as geloofsgemeenskap. Brueggemann (1995) argumenteer oortuigend dat hierdie aspek baie sentraal gestaan het in die prediking van die profete (en psalms) - en wat meer is: dit was die essensie van profetiese prediking. Hierin sien ons duidelik dat profetiese prediking nie primêr oor oordeel en dreiging gaan nie, maar oor belofte van 'n wêreld en 'n lewe wat anders kan wees. Myns insiens is Burger korrek as hy sê dat daar meer ruimte moet wees vir moontlikheidsdenke en verbeelding in die prediking oor die deugde (Burger et al. 1996:24)

Volgens Vosloo (1996:31) verstaan die wat op 'n moralistiese, wettiese wyse oor die Christelike deugde preek die aard van die prediking aangaande die deugde en die verhouding tussen wet en evangelie verkeerd. Die deugde-prediking bied juis die geleentheid om opnuut die boodskap van die genade aan te hoor (Cilliers 2004:11). Die imperatief van 'n deugsame lewe moet voortvloei uit die indikatief van God se genadige handelinge in en deur Jesus Christus en sterk gekoppel word aan 'n herskepte verstaan van die gelowige se eie identiteit. Die geloof moet só geïnternaliseer word dat dit in sekere lewensvaardighede vergestalt word en konkreet uitgeleef word. Dit is belangrik dat ons verstaan dat 'n deugde-etiek nie te kontrasteer is met 'n plig-etiek nie. Daar moet 'n dialogiese verhouding tussen hierdie twee bestaan. Die deugde gaan oor baie meer as net individualisties gerigte morele wette. Dit gaan ten diepste om mense in 'n bepaalde gemeenskap, wat op grond van 'n herskepte identiteit en hernuwe verstaan van God, die self en ander leef. Dit is dan ook tipies te sien in die Pauliniese etiek. Paulus gaan altyd uit vanaf die getransformeerde identiteit van die gelowige (indikatief) en die gevolglike appèl tot die leef van 'n nuwe lewe volgens daardie nuwe identiteit. Hierdie herskepte identiteit is egter nie staties nie - dit is herskeppend en vernuwend, dinamies groeiend (Ef 4:24; Kol 3:10). Die fokus vir Paulus val dus nie op die werke self soseer as wat dit val op die veranderde identiteit van die gelowige nie (vgl. Gal 5:1-26). Die sogenaamde vader van die Nuwe Perspektiewe op Paulus
(New Perspectives on Paul), James Dunn (2005:313-337), wys egter daarop dat die werke vir Paulus onlosmaaklik verbind was aan die nuwe selfverstaan. Vanuit die gelowige se identiteit behoort die etiek noodwendig voort te vloei (Wolter 2009:122). Tog is dit duidelik dat die indikatief-imperatief struktuur nie altyd in die praktyk so eenvoudig in die lewe van Christene as morele agente funksioneer nie. Dit is duidelik dat Paulus in sy skrywe aan gemeentes dikwels die gemeentes aangespoor het om weer hulle ware identiteit te besef en die gevolglike etiese lewe wat dit vereis na te volg.

Myns insiens funksioneer die Pauliniese etiek binne die konteks van wat etiese kenners as communitarianism beskryf (kyk Painter-Morland 2008:75). Laasgenoemde is 'n teleologiese benadering wat die proses beskryf waarvolgens normatiewe prioriteite (reëls of etiek of etos) in die konteks van bepaalde gemeenskappe gedefinieer word. Volgens communitarianism het elke groep 'n bepaalde telos of einddoel waarheen gestrewe word en ook dien as'n gedeelde bron van morele oriëntasie (vgl. ook Aristoteles). Hiervolgens is dit duidelik dat gemeenskaplike etiese gedrag bepaal en beïnvloed word deur gebruike (etos) en beginsels (etiek) wat ontwikkel is in die konteks van die bepaalde gemeenskap onder oë. Binne die konteks van en interaksie met die groep vind die individu dus homself as morele agent en word hy gevorm. Painter-Morland (2008) merk op:

$[A]$ community is a collection of individuals who participate in each others' lives and who have a number of significant beliefs, values and norms in common. These beliefs, norms and values are articulated in stories. The metaphors, symbols and ideas that are employed in such foundational narratives act as points of common orientation and allow the community to express and continually reaffirm its moral priorities and commitments.

(Painter-Morland 2008:76)

In die konteks van die gemeenskap is daar uit die aard van die saak bepaalde verteenwoordigers van die groep - diegene wat deur die groep aanvaar word as dié wat die hart van die groep weerspieël. In die Pauliniese gemeentes was Paulus so 'n figuur. Paulus was deur die geloofsgemeenskappe aan wie hy geskryf het 'n geestelike leier wie se voorbeeld die gemeente gevolg het (vgl. 1 Kor 4:16; 11:1; Fil 3:17). Paulus het dikwels sy gemeente aangespoor om sy voorbeeld te volg, aangesien hy van oortuiging was dat sy voorbeeld aan hulle geskoei is op die voorbeeld van Christus (vgl. 1 Kor 11:1). In sy mentorskap van Timoteus (2 Tim 1:13) en Titus (Tit 2:7) spoor hy hulle ook aan om sy voorbeeld te volg in leer en lewe wat uiteindelik teruggevoer kan word na dié van Christus. In sy interaksie met die gemeentes aan wie hy skryf sal Paulus dikwels in die konteks van morele krisis die gemeente terugneem na die grondnarratiewe, na die 'foundational narratives' (vgl. 1 Kor 1:10-17; Fil 2:5-11), en die impak daarvan op 'n nuwe verstaan van identiteit (Gal 6:15; 1 Kor 5:7; 2 Kor 5:17)

Vosloo (1996:33) is dus korrek as hy opmerk dat daar in die prediking aangaande morele kwessies baie gemaak kan word van morele vorming deur verhale, rolmodelle en vriende. In die proses van morele vorming speel verhale en voorbeelde 'n belangrike rol wat nie onderskat kan word nie. 'Verhale, meer as reëls en beginsels, is bepalend vir 'n mens se verstaan van moraliteit' (Vosloo 1996:33). Verhale boei die mens se verbeelding, vorm groepsidentiteit, raak emosies aan en motiveer hulle tot aksie. Die prediking bied die geleentheid om deur die vertel van die Bybelse verhale mense se verbeeldings te boei 'sodat hulle toegerus en gemotiveer word om op maniere te dink en te leef wat nie vroeër as opsies beskou is nie' (Vosloo 1996:33).

Dit is interessant om te sien hoe Paulus in sy heel eerste brief aan die Tessalonisense die geloofsgemeenskap motiveer in die klassieke exordium-gedeelte van die brief deur woorde wat 'n beeld skets van hoe die ander gelowiges en Paulus as leier die geloofsgemeenskap in Tessalonisense op 'n besonder positiewe wyse beskou. Die exordium skep die geleentheid vir Paulus om die gemeente te motiveer om in goeie gedrag te volhard deur 
'n emosionele appèl rakende hulle eer in die oë van mense. Vir die antieke mens was die eer in die oë van ander een van die belangrikste basisse van motivering. Die implikasie is dat indien die gemeente sou ophou met hulle 'goeie' etiese gedrag (Van Eck \& Kok 2010), hulle eer in die oë van mense afgebreek sal word. In sy brief, wat eintlik as 'n geskrewe preek beskou kan word, aangesien dit voorgelees moes word aan die gemeente (1 Tess 5:27), gebruik hy die implisiete etiese struktuur van eer en skaamte om sy hoorders te motiveer tot 'n bepaalde selfverstaan en gevolglike etiek. Paulus maak ook retories appèl betreffende die goeie voorbeeld wat die Tessalonisense voorhou en 'n tipos vir alle gelowiges geword het. Hierdie tipos is weer gebou op die voorbeeld van die leiers wat die evangelie aan hulle gebring het (nl. Paulus), wat op húlle beurt die voorbeeld van Christus navolg (1 Tess 1:6). Daar is 'n baie duidelike hiërargiese vloeiproses teenwoordig, waarin die etos of leefstyl van die gelowige teruggevoer kan word na dié van Christus. Christus dien as tipos alleen binne die raamwerk van die belydenisdimensie wat gekoppel is aan die Christusgebeure (lewe, dood en opstanding). In die Christelike nadenke aangaande morele vorming behoort dit dus ten diepste te gaan om die navolging van Christus en word ons getransformeer in die lig van ons verhouding met Hom en die geloofsgemeenskap om daardie voorbeeld te kontinueer. Deugsaamheid is nie noodwendig 'n doel op sigself nie, maar is die gevolg van 'n lewe met'n sekere gerigtheid wat op Christus in gehoorsaamheid aan God gefokus is. Etiek, spiritualiteit en (herskepte) identiteit is ten nouste aan mekaar verbonde (Vosloo 1996:34). Deur dissiplines soos gebed, meditasie, diens en aanbidding te beoefen, word 'n sekere habitus (gewoonte) juis bevestig en versterk (vgl. Aristoteles; kyk Painter-Morland 2008:75-81). Waar die band tussen etiek, spiritualiteit en identiteit ontbreek, ontaard die morele lewe dikwels in kortsigtige moralisme (Vosloo 1996:34), en preke raak verbeeldinglose morele lessies (Cilliers 2004:95).

Cilliers (2000:119) is dus reg as hy daarop wys dat daar in etiese prediking 'n nuwe visie vir die samelewing voorgehou (moet of kan) word op só 'n manier dat die visie in dade omgesit word. Die unieke van die Christelik-etiese prediking lê volgens Cilliers juis in die hoopgewende dinamika daarvan. Hierdie preke roep mense tot verandering op, maar laat hulle nie met die onmoontlike opdrag om te verander aan dit wat net God kan verander nie. Moralisme slaan volgens hom alle hoop uitmekaar, terwyl ware etiese prediking mense oproep tot verandering binne die werklikheid van die evangelie, wat 'n krag tot redding is vir elkeen wat glo (Rom 1:16) en in verantwoordelikheid hulself bind aan daardie leweskeppende evangelie. Dit is duidelik dat ons hier met 'n gans andere styl van prediking te doen het as dit wat ons onder moralistiese prediking geken het. Dit is 'n styl wat pastoraal uitnooi - om in die hoop te kom deel waarvan die Bybelse teks getuig (Cilliers 2000:119; Long 2009:64).

\section{SLOT}

Vir die Reformatore was wettisisme die grootste gevaar wat die prediking bedreig het. Luther het gesê dat waar die prediking wetties raak, daar niks meer van die genade van die evangelie oorbly nie. Vir Luther was die korrekte verstaan van die verhouding tussen wet en evangelie van kardinale belang. Wettiese prediking word gekenmerk deur min indikatiewe en baie imperatiewe. Dit is prediking waar die vermoë van die mens in sy vervallenheid oorskat word en die verlossingsdaad van Christus en die genade van God in die evangelie onderskat word. Kortweg, dit fokus dermate op die mens en die wette en reëls wat hy moet nakom dat God, en die basis van 'n herskepte identiteit, uit die oog verloor word. Saam met Johan Cilliers (1996) kan ons sê dat hierdie tipe prediking hom besig hou met die 'uitwissing van God op die kansel'. Hierteenoor staan die 'hermeneutiese model vir evangelieprediking' wat poog om hierdie dergelike probleem te oorkom. Laasgenoemde lei in die eerste instansie tot die hernude 'uitwysing van God op die kansel'. Hier staan nie die mens nie, maar God en Sy handelinge in die sentrum. Dan kommunikeer die prediker meer oor wat God (kan) doen en minder oor wat die gevalle mens kan doen. Só leef ons as Bybelse pelgrims 'agteruit vorentoe' met nuwe hoop wat gewortel is in die groot verlossingsdade van God in die ryke verlede (Long 2009) - en doen ons dit saam as geloofsgemeenskap wat mekaar help vorm in lyn met die (herontdekte) oorspronklike begrondingsnarratief van ons geloof.

\section{LITERATUURVERWYSINGS}

Allen, D., 1989, Christian belief in a postmodern world: The full wealth of conviction [Christelike geloof in ' $n$ postmoderne wêreld: Die volle rykdom van die veroordeling], Westminster, Louisville.

Bosch, D.J., 1991, Transforming mission, paradigm shifts in the theology of mission [Transformasie missie, paradigma verskuiwings in die teologie van die sending], Oribis Books, New York.

Bourdieu, P., 1991, Language and symbolic power [Taal- en simboliese mag], Harvard University Press, Cambridge.

Brueggemann, W., 1995, The Psalms and the life of faith [Die Psalms en die lewe van geloof], Augsburg Fortress, Minneapolis.

Burger, C.W., 1995, Gemeentes in transito, Lux Verbi, Kaapstad.

Burger, C.W., 1999, Gemeentes in die kragveld van die Gees, Lux Verbi, Kaapstad.

Burger, C.W., 2001, Ons weet aan wie ons behoort, Lux Verbi, Kaapstad.

Burger, C.W., Müller B.A. \& Smit D.J., 1996, Riglyne vir die prediking oor die Christelike deugde, Woord teen die lig III/4, Lux Verbi, Kaapstad.

Burridge, R.A., 2007, Imitating Jesus. An inclusive approach to New Testament ethics, [Imiteer Jesus. 'n Inklusiewe benadering tot Nuwe Testament Etiek] Eerdmans, Grand Rapids.

Campbell, W.S., 2008, Paul and the creation of Christian identity [Paulus en die skepping van die Christelike identiteit], T\&T Clark, New York.

Cilliers, J., 1996, Die uitwissing van God op die kansel, Lux Verbi, Kaapstad.

Cilliers, J., 1998, Die uitwysing van God op die kansel, Lux Verbi, Kaapstad.

Cilliers, J., 2000, Die genade van gehoorsaamheid, Lux Verbi, Kaapstad.

Cilliers, J., 2003, 'Die verhouding tussen Skrifbeskouing en prediking', Nederduitse Gereformeerde Teologiese Tydskrif 44(12), 20-28.

Cilliers, J., 2004, Die lewende stem van die Evangelie: Nuut gedink oor die basiese beginsels van prediking, SUN Press, Stellenbosch.

Dijk, K., 1955, Dienst der prediking [Diens van prediking], Kok, Kampen.

Du Toit, A.B. (ed.), 2009, Focussing on the message [Fokus op die boodskap], Protea, Pretoria.

Dunn, J., 2005, The new perspectives on Paul [Die nuwe perspektiewe oor Paulus], Eerdmans, Grand Rapids.

Ebeling, G., 1967, Wort und Glaube I [Woord en geloof], Mohr Siebeck, Tübingen.

Friedman, T.L., 2008, The world is flat. A brief history of the twentyfirst century [Die wêreld is nie rond nie. 'n Kort geskiedenis van die twintigste eeu], Farrar, Straus and Giroux.

Grobler, C.S., 1983, 'Kategismusprediking - Is dit Skrifprediking?', ThM vehandeling, Potchefstroomse Universiteit vir Christelike Hoër Onderwys (nou Noordwes Universiteit), Potchefstroom.

Johnston, G.J., 2001, Preaching to a post modern world [Prediking vir 'n post-morderne wêreld], Baker Books, Grand Rapids.

Joubert, P., 2008, 'Die belydenis van Jesus Christus in die prediking om eietydse hoorders tot geloof te bring', PhDproefskrif, Departement Praktiese Teologie, Universiteit van Pretoria.

Joubert, S.J., 2010, Jesus - 'n radikale sprong, CUM, Kaapstad.

Kok, J., 2008, 'Siekte en gebrokenheid teenoor genesing en restourasie in Johannes', PhD proefskrif, Departement Nuwe Testament, Universiteit van Pretoria.

Kok, J., 2009, 'Die Opstanding van Jesus as Kulminerende Genesingshandeling in Johannes', Verbum et Ecclesia 30(1), 112-147. 
Kok, J. \& Kok, G.J., 2010, Die metodiek van eksegese, Crink, Pretoria.

Kok, J. \& Niemandt, N., 2009, 'Rediscovering a missional incarnational ethos '[Herontdekking van 'n missionale, verpersoonlike etos] HTS Teologiese Studies/Theological Studies 65(1), 1-7.

Koopman, N. \& Vosloo, R., 2002, Die ligtheid van die lig. Morele oriëntasie in 'n postmoderne tyd, Lux Verbi, Kaapstad.

Lategan, B., 2009, 'New Testament hermeneutics (part 1 \& 2): Defining moments in the development of Biblical hermeneutics [Nuwe Testamentiese Hermeneutiek (deel 1 \& 2): Bepaalde oomblikke in die ontwikkeling van Bybelse Hermeneutiek]', in A.B. Du Toit (ed.), Focussing on the message, pp. 13-63, 65-105, Protea, Pretoria.

Long, T.G., 1990, 'The use of scripture in contemporary preaching [Die gebruik van die Skrif in hedendaagse prediking]', Interpretation 44(4), 341-352.

Long, T.G., 2009, Preaching from memory to hope [Van nagedagte na hoop: 'n Prediking], Westminster John Knox Press, Louisville.

McGrath, A.E., 1990, The genesis of doctrine [Die ontstaan van die leer], Basil, Blackwell.

Meeks, W.A., 1993, The origins of Christian morality [Die oorsprong van Christelike moraliteit], Yale University Press, New Haven.

Miller, R., 2004, The millennium matrix: Reclaiming the past, reframing the future of the church [Die millennium matriks: Die terugwinning van die verlede, her-evaluering van die toekoms] , Jossey-Bass, San Francisco.

Murray, W.E., 2006, Geographies of globalization [Geografie van globalisering], Routledge, New York.

Niemandt, N., 2007, Nuwe drome vir nuwe Werklikhede, Lux Verbi, Wellington.

Oberholzer, J.P., 1989, ‘Die Heildelbergse kategismus in sy eerste jare', HTS Teologiese Studies/ Theological Studies 45(3), 598-610.

Painter-Morland, M., 2008, Business ethics as practice: Ethics as the everyday business of business [Sake-etiek as 'n oefenlopie: Etiek as die alledaagse bedryf van besigheid], Cambridge University Press, Cambridge.

Peeters, T.J., 2003, Re-imagine! Business excellence in a disruptive age [Her-verbeel! Besigheid voortreflikheid in 'n verdeelde tydperk], Dorling Kindersley, London.

Pieterse, H.J.C., 1979, Skrifverstaan en prediking. Die verhouding van woordgebeure enverstaansgebeure by Gerhard Ebeling as antwoord op die nood van die prediking, N.G. Kerkboekhandel, Pretoria.

Pieterse, H.J.C., 2005, 'Die rol van Godskennis in die ontmoetingsgebeure met God in die prediking', In die Skriflig 39(3), 409-422.

Powell, M.A., 2009, Introducing the New Testament [Die bekendstelling van die Nuwe Testament], Baker Academic, Grand Rapids.

Ridderbos, H.N., 1997, Paul: An outline of his theology [Paulus: 'n Uiteensetting van sy teologie], Eerdmans, Grand Rapids.

Roxburgh, A.J., 2005, The sky is falling: Leaders lost in transition [Die hemel is besig om te val: Leiers verlore in oorgang] Allelon, Eagle.

Roxburgh, A.J., 2010, Missional map-making: Skills for leading in transition [Sendingskartografie: Vaardighede vir leierskap in oorgang], Jossey Bass, San Francisco.
Smit, A., 1995, Nuut gedink oor leierskap in gemeentes, Lux Verbi, Kaapstad.

Spangenberg, I.J.J., 2003, 'Wat moet ons weet en wat kan ons nog glo?', Nederduitse Gereformeerde Teologiese Tydskrif 44(1\&2), 147-160.

Spangenberg, I.J.J., 2004, 'Om oor God te praat: 'n Kritiese oorsig van gesprekke onder Afrikaanssprekende Christene van die gereformeerde tradisie (1998-2003)', Verbum et Ecclesia 25 (1), 274-293.

Spoelstra, B., 1991, 'Die sogenaamde kategismuspreek vanwaar, waarom en hoe?', In die Skriflig 25(3), 363-382.

Steyn, G.J., 2005, 'Die NG Kerk se identiteitskrisis: Aanloop, terreine van beïnvloeding en Reaksies', Nederduitse Gereformeerde Teologiese Tydskrif 46(3\&4), 550-559.

Sweet, L. \& Viola, F., 2010, Jesus manifesto: Restoring the supremacy and sovereignty of Jesus Christ [Jesus manifest: Die herstel van die oppergesag en die soewereiniteit van Jesus Christus], Thomas Nelson, Nashville.

Turner, J.H., 1974, The ritual process: Structure and anti-structure [Die rituele process: Struktuur en anti-struktuur], Cornell University Press, Ithaca.

Van der Watt, J.G., 2002, Hoelees ons die Bybel?, CUM, Vereeniging.

Van der Watt, J. G., 2005, 'Huidige uitdagings vir die Ned Geref Kerk rakende fasette van skrifhantering', Nederduitse Gereformeerde Teologiese Tydskrif 46(1\&2), 247-259.

Van der Watt, J.G. \& Kok, J., 2010, 'Violence in John', in J.W. Van Henten \& P. De Villiers (eds.), Violence in the New Testament, Brill, Leiden (forthcoming).

Van der Watt, J.G., 2010, 'Die skadukant van die Johannese etiek', seminaarlesing van die NENT-byeenkoms in die winter van 2010, Departement Nuwe Testament, Universiteit van Pretoria.

Van Eck, E. \& Kok, J., 2010, 'Ensiklopedie van die Nuwe Testament en die sosiale waardes van die antieke Mediterreense wêreld van die eerste eeu', BTh-lesingmateriaal, Departement Nuwe Testament, Universiteit van Pretoria.

Vosloo, R., 1996, 'Etiese perspektiewe op die Christelike deugde met die oog op die prediking', in C.W. Burger, B.A. Muller \& D.J. Smit (reds.), Riglyne vir die Prediking oor die Christelike Deugde, Woord teen die Lig III/4, Lux Verbi, Kaapstad.

Weatley, M.J., 2006, Leadership and the new science. Discovering order in a chaotic world [Leierskap en die nuwe wetenskap. Ontdek orde in 'n chaotiese wêreld], Berrett-Koehler, San Francisco.

Wethmar, C.J., 1977, Dogma en verstaanshorison, Rodopi, Amsterdam.

Wethmar, C.J., 2003, 'Mdiv-lesingaantekeninge', Departement Dogmatiek en Christelike Etiek, Universiteit van Pretoria.

Wolter, M., 2009, Theologie und Ethos im frühen Christentum [Teologie en etiek in die vroeë Christendom], WUNT 236, Mohr Siebeck, Tübingen.

Zimmermann, R., 2009a, 'The implicit ethics of New Testament writings [Die ingelsote etiek van die Nuwe Testament]', Neotestimentica 43(2), 399-432.

Zimmermann, R. (ed.), 2009b, Jenseits von Indikativ und Imperativ. Kontexte und Normen neutestamentlicher Ethik/Contexts and Norms of New Testament Ethics, Bd. 1, WUNT 238, Mohr Siebeck, Tübingen.

Zimmermann, R. (ed.), 2010, Moral language in the New Testament [Morele taal in die Nuwe Testament], Mohr Siebeck, Tübingen (forthcoming). 